\title{
Corrigendum: The gene encoding phosphodiesterase 4D confers risk of ischemic stroke
}

S Gretarsdottir, G Thorleifsson, S Th Reynisdottir, A Manolescu, S Jonsdottir, T Jonsdottir, T Gudmundsdottir, S M Bjarnadottir, O B Einarsson, H M Gudjonsdottir, M Hawkins, G Gudmundsson, H Gudmundsdottir, H Andrason, A S Gudmundsdottir, M Sigurdardottir, T T Chou, J Nahmias, S Goss, S Sveinbjörnsdottir, E M Valdimarsson, F Jakobsson, U Agnarsson, V Gudnason, G Thorgeirsson, J Fingerle, M Gurney, D Gudbjartsson, M L Frigge, A Kong, K Stefansson \& J R Gulcher

Nat. Genet. 35, 131-138 (2003).

In Supplementary Table 2 online, SNP 41 was incorrectly labeled as rs152312. The correct label is rs12153798.

\section{Corrigendum: Mutations in a novel gene encoding a CRAL-TRIO domain cause human Cayman ataxia and ataxia/dystonia in the jittery mouse}

J M Bomar, P J Benke, E L Slattery, R Puttagunta, L P Taylor, E Seong, A Nystuen, W Chen, R L Albin, P D Patel, R A Kittles, V C Sheffield \& M Burmeister

Nat. Genet. 35, 264-269 (2003).

This paper states that "affected subjects and family members...gave informed consent approved by the University of Miami Institutional Review Board.” This is an error. Informed consent was approved by the Minister of Health, Grand Cayman Islands, and the Research Committee of the Grand Cayman Islands Government, and all families and all subjects able to do so gave informed consent.

Cor nematode and mammalian neurons

J A Parker, M Arango, S Abderrahmane, E Lambert, C Tourette, H Catoire \& C Néri

Nat. Genet. 37, 349-350 (2005).

The authors thank M. Hayden and C. Wellington for providing cDNAs encoding mutant 128Q N-terminal huntingtin. controls brain size

J Bond, E Roberts, K Springel, S Lizarraga, S Scott, J Higgins, D J Hampshire, E E Morrison, G F Leal, E O Silva, S M R Costa, D Baralle, M Raponi, G Karbani, Y Rashid, H Jafri, C Bennett, P Corry, C A Walsh \& C G Woods

Nat. Genet. 37, 353-355 (2005).

The name of the fourth author was incorrect. The correct name is Sofia B. Lizarraga. 